\title{
Arnold Schönberg and Musica Artificiosa. A rationality in the Musical Composition
}

\author{
Vladimír Fulka / martinu@post.sk \\ Institute of Musicology, Slovak Academy of Sciences, Bratislava, SK
}

\begin{abstract}
Concepts musica artificiosa and rationality are part of modern aesthetic-philosophical discours of music. Arnold Schönberg and Anton Webern can be considered an originators of the discours of rationalism. Schönberg as a theoretician and composer revived the ancient topic of music history and brought it to the fore. Music of the 20th century discovered its potential of rationality, which was possible due to new relationships between the theory of music and composition, strong involvement of composers in a theoretical reflection of their music. A personal union of a theoretician, philosopher, aesthetician and composer led even to blurring of a traditional border line between theoretical reflection and composition. Composers of the darmstadt serial avant-garde epitomize this cultural phenomenon of rationalism, but the originator was A. Schönberg. Th. W. Adorno was first schönbergian aesthetician-theoretician who explored phenomenon of Schönberg's rationality in its ambivalency and possible negative implications. His analyses in confrontation with Schönberg's reflection are the point of departure of this study.
\end{abstract}

\section{Keywords}

musica artificiosa, rationalism, irrationalism, dodecaphony, twelve tone technique, structuralism, scientism, philosophy of language, musical construction, constructivism, order, determinism, totality of relationships 
Latin concept musica artificiosa encompasses a wide semantic spectrum: art, abilities, skills, artisans, trade, technology. Adjective artificiosus might connote artificiality, unnaturalness, in relation to music highly rational compositonal procedures, rationality in music. It would be possible to widen further the sematic spectrum of musica artificiosa: artificiosus, artificial as something that is very exclusive and highly artistic, maybe esoteric, not for "common" lovers of music, but rather for a narrow circle of hypersensitive privies; sometimes it might have been the elitist art for an artist himself. Mediaval concepts musica mundana, Ars subtilior, Ars nova, as well as Musica reservata from the late renaissance may be examples of musica artificiosa and rationalis. Concept Musica artificiosa may remind us l'art pour l'art and decadence, the fin de siecle, atmosphere of a famous novel $\grave{A}$ Rebours (1884) of the french writer Joris-Karl Huysmans ${ }^{1}$ with its possible ethical implications in the european culture. Ars artificiosa is a more global philosophical-cultural phenomenon in which music played a distinctive role.

Music of the 20th century, the Second Vienna School and the post-war serialism of Darmstadt composers revived ancient traditions and global cultural phenomenon of the musica artificialis, a musical rationality. Arnold Schönberg might be considered "discoverer" of these aesthetic-philosophical phenomena in the 20th century. In his essay Heart and Brain in Music from his book of english lectures and essay Style and Idea (1950) Schönberg declared: "I believe that a real composer writes music for no other reason that it pleases him. Those who compose because they want to please others and have audience in mind are not real artists". ${ }^{2}$ Schönberg brought to the fore an ancient dilemma of a rational element of music in a contrast to its emotionality and irrationality. Typical concepts are cerebral, cerebralism which should have to have a superiority over emotions in a composition. Schönberg's reflections may recall similar reflections on compositional process of Igor Stravinsky.

The dodecaphony was considered by Schönberg to be a renaissance of an intellectual dimension and racionalism in music of the 20th century. It was intended to be a challenge to a limitlessness and redundancy of the late romanticism, to Schönberg's own postromantic, hyperchromatic, atonal and expresionistic musical style. Schönberg's aim was to give the compositional process new firm limits, an economy and austerity, impose a new concious controll to what became hypertrophic, chaotic and confused. The tonal system and impressionistic sound element in music were considered to be a source of this hypertrophy. What Schönberg missed in the music of R. Wagner and C. Debussy was a constructive dimension. "Debussy harmonies, without constructive meaning, often served the coloristic purpous of moods and pictures." A purpose and an aim of the new method of composition was a comprehensibility of music, or a renewal of the "lost" comprehensibility. It is in this lecture Composition with Twelve Tones where Schönberg was convinced to find deeper and more universal roots of his compositional method - a need of the total organisation and rationality, a systemisation and order, which is universal in the

1 In the english translation Against the Grain, or Against Nature, in the Czech translation Naruby.

2 SCHÖNBERG, Arnold. Heart and Brain in Music. In SCHÖNBERG, Arnold. Style und Idea. New York: Philosophical Library, 1950, p. 154.

3 SCHÖNBERG, Arnold. Composition with Twelve Tones. In SCHÖNBERG, Arnold. Style und Idea, op. cit., p. 104. 
composition. "[...] the desire for a conscious controll of the new means and forms will arise in every artist's mind;and he will wish to know consciously the laws and rules which govern the forms, which he has conceived 'as in a dream.'" ${ }^{4}$ Schönberg's postulate may sound as a challenge to the generally accepted role of irrationality and intuition in a composition. Is a desire for a fully conscious control, to have all conceived unconsciously under the rational controll in music, really so universal? Luckily, with Schönberg it was rather theory than compositional practice: in it not all was under his strict control of system, as Th. Adorno notices in his analyses.

Schönberg's aim was to prove that the dodecaphonic method of a composition was nothing more than a new, more strict and more perfect version of old, now worn out rules of the tonality, harmony, rythm and counterpoint, inherent in the musical material. Therefore Schönberg in his lecture on twelve tone composition quoted not only his own atonal and dodecaphonic compositions, but also canonical inversion procedures in L. v. Beethoven's String Quartete Fa major, no. 16, op. 135. Schönberg's idea of the dodecaphony was the idea of a deep continuity of the evolutive variation (entwickelnde Variation), the continuity of classical-romantic music in the dodecaphony. Schönberg's essay Brahms the Progressive (1933, from Style and Idea) was intended to be his declaration of an adherence to the Brahms's message (although he felt himself, too, to be a Mozart's disciple). In analysis of the Brahms's music Adorno was highlighting the rational, "cerebral" dimension of his compositional procedures. In this sense, Brahms was for Schönberg "the progressive". "If a mathematician's or chess player's mind can perform such miracles of the brain, why should a musicians's mind not be able to do it? $?^{\text {"5 }}$ A composer should have to be as "cerebral" as a theoretician. Schönberg referes to the accomplishments of mathematicians, constructeurs and architects as a models of rationality to be followed by musicians. For composer like Schönberg there was a deficiency of rationality in music of his time, and abundance, redundancy of emotionality. "No doubt all those who supposedly create cerebrally - philosophers, mathematicians, constructeurs, inventors, theorists, architects - keep their emotions under controll and preserve the coolnes of their heads, even though imagination often inspires them." ${ }^{6}$ Counterpoint structures and combinations of the string sextet Transfigured Night (Verklärte Nacht) quoted in Heart and Brain were described by Schönberg not as a result of his spontaneous inspiration, but a result of the cerebral reflection, even "extra-musical intention". It is remarkable enough that in this case the example of the "rational composition" was taken from his post-romantic chromatic work (1899), with Schönberg's dodecaphony being still in a very distant future. In this way Schönberg intended to "de-mythologize" his music and music of others. But in another essay in his book of essays, New Music, Outmoded Music, Style and Idea ${ }^{7}$ he found it necessary to defend himself against suspicions and accusations that he is a composer-rational constructeur and ingenieur without emotions, phantasy and inspiration.

4 Ibidem, p. 106.

5 SCHÖNBERG, Arnold. Brahms the Progressive. In SCHÖNBERG, Arnold. Style und Idea, op. cit., p. 98.

6 SCHÖNBERG, Arnold. Heart and Brain in Music. In SCHÖNBERG, Arnold. Style und Idea, op. cit., p. 153.

7 Ibidem, p. 37-51. 
It was Schönberg's theoretical reflection and composition which instigated new relations between the theory of music and musical composition in the 20th century:strong, albeit ambivalent personal union of a composer and a theoretician, composers reflecting and explicating his own works, creating systematic compositional theories on the ground their own music. Therefore Schönberg's musical analyses are focused mainly on his own compositions, although in the book Style and Idea we find a wide style spectrum of the analyzed music from J. S. Bach and W. A. Mozart to G. Mahler. Schönberg's compositions were strongly determined by his systematic, theoretical reflexions. This cultural phenomenon, manifestation of "musica artificiosa", might be deemed "composition as a fulfilment of the theory", in contrast to traditional thesis "music as a refutation of the theory". "Composition as a fulfilment of the theory" was an aesthetics typical for P. Boulez's serial avant-garde, but originally inspired by Schönberg. In Schönberg's reflection on dodecaphony we can find nearly a „boulezian”, "scientistic” idea of the dodecaphonic composition, the idea of an advance "from a mere technical device to the rank and importance of scientific theory." 8 Schönberg's very frequent utilisation of the concept musikalische Logik is significant as a manifestation of these "scientistic" ambitions. Schönberg's dodecaphony as model of "scientific" composition became an incentive for his succesors and disciples.

For darmstadt composers and especially for Milton Babbit the role of composer is similar to that of physicist or mathematician, rather than to the role of creator of music for listeners: composition not as an aesthetic object but rather a solution of an scientific and intelectual problem, as if in the 15th century in Franco-Flamish school. In Babbit's view the twelve tone composition was the most influential hypothetic-deductive system in the history of music, although it was not the only one. At the end of Boulez's analysis of Stravinsky's ballet Rite of Spring Boulez wrote about a scientific essence of musical analysis, in his frequently quoted declaration. "Must I repeat that I have not pretended to discover a creative process, but concern myself with the result whose only tangibles are mathematical relationsships?" ${ }^{* 9}$ Boulez's treatise Penser la musique aujourd'hui $(1964)^{10}$ became a manifest of rationalism in music. There was a flavour of exclusivity of musica artificiosa in the status of serialism as the only possible way of composition. For R. Leibowitz dodecaphonyserialism was the only genuine and inevitable expression of the musical art of the era. ${ }^{11}$ In Boulez's view, composers not utilising serial technique are useless, meaningless ones. In this sense B. Kutschke in her book Wildes Denken in der Neuen Musik described music of the darmstadt avant-garde as compositional procedures with the aim to derive all parameters and dimension from principles of order. The parameters are coded through numbers (in Zahlenreihen schifriert) and than combined, permutated, following a logic of the mathematics (quasi einer mathematischen Logik folgend, permutiert und miteinander kom-

$8 \quad$ Ibidem, p. 109.

9 BOULEZ, Pierre. Notes of Apprenticeship. New York: 1968, p. 142.

10 BOULEZ, Pierre. Boulez on Music Today. Cambridge-Massachusetts: Harvard University Press, 1971.

11 LEIBOWITZ, René. Schönberg et son école. L'etat contemporaine du langage musicale. Paris 1947; TARUSKIN, Richard. Music in the Late 20th Century. The Oxford History of Western Music. Oxford University Press, 2010 , p. 16. 
biniert werden). ${ }^{12}$ Kutschke's definition of the rationalism in music refers to the boulesian serial avant-garde, but these phenomena can also refer to A. Schönberg.

It seems to be meaningful and useful, even necessary, to explore the topic of Schönberg's music rationality and musica artificiosa in the contexts of the serialism, in confrontation both of them, as Th. W. Adorno did it in his late studies. He pointed both to similarities and incoherencies between them, Schönberg and Webern as originators of tendencies of serialism. Schönberg was rejected by P. Boulez in his article "Schönberg est mort" (1952). In this manifest Schönberg's music was by declared a dead value over his insufficient radicalism in applying of rows, over his subjectivism, and not cutting himself off radically from all musical traditions.

The serial composition of the Darmstadt school was not only a result of the continuity of Schönberg's tradition and legacy. It was also a result of the strong influence of the linguistic and anthropological structuralism and the neopositivistic philosophy of language. P. Boulez, composer and mathematician, appealed as a composer to the tradition of R. Descartes's Discours de la méthode. He saw his task of a composer in an application of a peremptory logic in the musical composition. P. Boulez together with I. Xenakis spoke of a necessity of the new higher formalism in music, in theory, analysis and in the compositional practice: a formalism in footsteps of the linguistic formalism and semiotics. "Structuralist thinking tends to blur the line between analysis and composition since both can be interpreted as a kind of symbolic activity based on construction of symbolic model of the object [...] reason that structuralism could color creative musical activity has to do with Boulez tendency to engage concurrently in theoretical/analytical activity and compositional activity." ${ }^{13} \mathrm{R}$. Barthes spoke in his essay L'Activité Structuralist (1963) of parallels between structuralist teories G. G. Granger, N. Trubetzkoy and C. L. Strauss on the one side, and artistic visions of a dutch painter P. Mondrian, music of P. Boulez and novels of Michel Butor on the other side.

Key concepts of Schönberg's atonality, dodecaphony in his theory and compositional practice referred to a musical construction, strict, or integral organisation, order and law. These concepts of rationality were a basis of the first schönbergian and webernian aesthetic-philosophical reflection and a reflection of serialism in Th. W. Adorno's musicology. There is a high frequency of these concepts and its variants in Adorno's studies and articles: Prinzip (Ideal) der Durchkonstruktion, Determinismus, Durchorganisation, Ideal des integralen Komponierens, Totalität von Zusammenhängen. For Adorno strongly influenced by Schönberg, a principal key to "new music", even aesthetic ideal seemed to be totality of relationsships. We find figurative expressions in similar meaning, relentless iron linking, close-knit relations in musical material (unerbittliche, eiserne Verklammerung des musikalischen Zusammenhangs, der Konstruktion, Bedürfniss nach einer Klammer). ${ }^{14}$ In his study Reaktion und Fortschritt (1930).Adorno even used for dodecaphony metaphor

12 KUTSCHKE, Beate. Wildes Denken in der Neuen Musik. Die Idee vom Ende der Geschichte bei Theodor W. Adorno und Wolfgang Riehm. Würzburg: Verlag Königshausen \& Neumann, 2002, p. 47.

13 GOLDMAN, Jonathan. The Musical Language of Pierre Boulez. Writings and Compositions. New York: Cambridge University Press, 2011, p. 20.

14 ADORNO, Theodor Wiesengrund. Neue Musik heute. In Theodor W. Adorno, Gesammelte Schriften in 20 Bänden. Musikalische Schriften V, Band 18. Frankfurt am Main: Suhrkamp, p. 129. 
thickness of work without any windows (fensterloses dichtes Werk). According to the principle of integral composition each tone has to be strictly determined by a system. B. Kutschke's definition of the serialism was also based on concepts of rationality as a construction, "systemische Totalität" deducible from the principles of order. ${ }^{15}$ The title of her book Wildes Denken in der neuen Musik is paraphrasing the title of the book of C. L. Strauss La pensé sauvage (1962), with philosophical allusions of structuralism, which was not Adorno's philosophical position. He was hegelian and marxist, in the end of hermeneutic orientation. ${ }^{16}$ Kutschke's concepts of wild thinking, music constructivism are in fact ambivalent as an aesthetic quality and value of serial music. The book Wildes Denken is about Adorno and a group of young German postmodern composers's in the seventies/eighties of the 20th century in their "revolt", all-out refusing and condemning of the entire serial avantgard. It was revolt against rationalism and constructivism, against music which is not any more intended by its composer to be listened to. ${ }^{17} \mathrm{~A}$,spiritual father" to these german "angry young men" was Adorno with his kranichstein-darmstadt essays Aging of the New Music (Das Altern der neuen Musik, 1954) and Toward an Informal Music (Vers une musique informelle, 1960). In these essays Adorno was also in "revolt" against the serial avant-garde and partially against Schönberg. Aesthetic manifests of W. Rihm, and Adorno's schönbergian-webernian studies may be inspiration to evaluate Schönberg's rationalism as ambivalent, equivocal and contradictory phenomenon, with its possible,fateful consequences”. Adorno's attitude to Schönberg was ambivalent, but his attitude to the boulesian-stockhausenian serialism unambiguously disapproving, negative one. It was manifestation of Adorno's dialectical ambivalency of schonbergian phenomenon as we find it especially in his book Philosophie der neuen Musik (1949).

In his early schönbergian essays Adorno was close to see the dodecaphony in a priviledged position, overestimating an order, constructivism and strict organisation of musical material, maybe reminding Boulez. He underestimated a relevance of other styles, orientation and cultures in music of the 20th (neoclassicism, neofolclorism, jazz). Adorno, in contrast to the composer Schönberg, was not only composer but also a graduated philosoper, aestetician and sociologist of the hegelian-marxist orientation, affiliated to the neomarxist Institut für Sozialforschung / Frankturter Schule at the Frankfurt University. Hegelian and neomarxist paradigms of this school were the basic epistemological frames in the interpretation of Schönberg's music and its rationality. Therefore, dodecaphony was interpreted by him as a manifestation of the historical inevitability, necessity, the manifestation of the racionality of history (rationale Vollzug des geschichtich Notwendigen, geschichtlichen Zwanges). ${ }^{18}$ It is a preformation, a pre-imprinting of the material of music in the history (Vorformung, Vorprägung des Materials). On the basis of Schönberg's music Adorno formulated the theorem of progress of musical material (Theoreme von dem Fort-

15 KUTSCHKE, Beate. Wildes Denken in der Neuen Musik, op. cit., p. 47.

16 In English translation Savage Mind.

17 B. Kutschke pays attention to this group and its anti-avant-gard program, to composers Wolfgang Rihm, Hans-Jürgen von Bose, Manfred Trojahn and others.

18 ADORNO, Theodor W. Zur Zwölftontechnik. In ADORNO, Theodor Wiesengrund. Gesammelte Schriften in 20 Bänden, op. cit., Bd 18., p. 364, 366. 
schritt des musikalischen Materials). ${ }^{19}$ In his theorem Adorno used hegelian and marxian concepts sedimented spirit (Sedimentierter Geist) and objectified subjectivity (vergegenständlichte Subjektivität). Adornian idea of the dodecaphony as a historical necessity was anticipated by Schonberg. The method of composing with twelve tones grew out of necessity, ${ }^{20}$ i.e. out of the historical necessity.

A point of departure of Adorno's schönbergian discourse of rationality, progress, regress, freedom were the thesis from Hegel's Vorlesungen über die Philosophie der Geschichte (1837), although it was also Marx's Theses on Feuerbach (1845). For Adorno the history was a manifestation of the world spirit, which is reason(Vernunft), rationality and freedom. Adorno's philosophical-historic concept of rationality is a racional-teleological one: The history of music is heading to the twelve tone organisation as its fulfillment, to the highly rational composition-construction. It is philosophy-aesthetics of progress and avant-garde. A task of the progresive composer is to submit himself to the dictum of history, accepting what the history is demanding from him. He has to listen to the "voice of history": determinism is the true freedom of a composer, the dialectical paradox of freedom in unfreedom, a blind following of a dictate of the history "in aller Freiheit des Psychischen kann ein Werk seiner materialen Konstitution nach gerade völlig unfrei, blinder Vollzug eines historischen Diktums sein." ${ }^{21}$ According to Adorno's essay Der dialektische Komponist (1934), Schönberg was a "dialectic composer" because he listened to the "voice of history." I. Stravinsky, P. Hindemith, B. Bartók, L. Janáček did not pursued this progressive orientation.

In his monography Dialectic of Enlightment (Dialektik der Auklärung, 1944) Adorno, together with Max Horkheimer formulated specific neomarxian interpretation of hegelian dialectics of history, criticism western civilisation and a tradition of enlightment: progress and freedom of the western industrial-bourgeois society reversed, in their negation. Rationality, the instrumental reason which is instrument of power and subduing of nature, gets in the western society out of control; the result is a self-alienation, reification (Vergegenständlichung) of social consciousness. Adorno's Dialectic anticipated in his early lecture Die Idee der Naturgeschichte (1932) was a part the wider ideological current of frankfurt neomarxian philosophy (critical theory) and sociology, represented by M. Horkheimer, G. Lukács and M. Weber, inspired by them. The founder of the sociology (sociology of music) Max Weber spoke about disenchantment of the World (Etzauberung der Welt) as a continual intellectualisation and rationalisation of the western society. Hypertrophic intellectualisation, secularisation and dechristianisation caused a lost of an irrational part of human being, magic and mystery, lost of a sense for art. ${ }^{22}$ Man in

19 KLEIN, Richard, KREUTZER, Johann, MÜLLER-DOOHM, Stephan (Hrsg.). Adorno Handbuch / LebenWerk-Wirkung. Stuttgart-Weimar: Verlag J. B. Metzler, 2011, p. 47-58. Theorema was formulated in various early texts of Adorno, e. g. Zur Zwölftonmusik, Der dialektische Komponist, Reaktion und Fortschritt.

20 SCHÖNBERG, Arnold. Composition with Twelve Tones. In SCHÖNBERG, Arnold. Style und Idea, op. cit., p. 103.

21 ADORNO, Theodor Wiesengrund. Reaktion und Forschritt. In ADORNO, Theodor Wiesengrund. Gesammelte Schriften in 20 Bänden, op. cit., Band 17, p. 135.

22 WEBER, Max. Wissenschaft als Beruf; Politik als Beruf. In MOMMSEN, Wolfgang J. (Hrsg.). Studienausgabe der Max-Weber-Gesamtausgabe. Abt. 1, Bd 17. Tübingen: J. C. B. Mohr, 1994, S. 1-24. 
the western society became a slave of the calculating reason. Der Mensch wird zum Knecht eines stahlharten Gehäuses der berechenbaren Vernunft. ${ }^{23}$

In M.Weber's sociology there are not only general historical, sociological, religious and cultural contexts and topics of rationality. He was the first who formulated this topic in relation to music, in his essay Die rationalen und soziologischen Grundlagen der Musik (1921), as a marxist philosopher.

Paradigms of rationalism from Frankfurt school, its Critical theory (Kritische Theorie) could have been applied to dodecaphony, as Adorno's Philosophie der neuen Musik (1949) demostrates. Adorno's book was written contemporaneously with Dialektik der Aufklärung, even as a kind of "musical version" of it. In the first part of the book Schönberg und Fortschritt, Schönberg's dodecaphony was presented as a progressive phenomenon inevitably reversed in a regress, as a manifestation of excesive rationality pervading like a "cancer" the whole western society. ${ }^{24}$ The twelve tone technique became manifestation of an estranged power of rationality, supressing a subject and his autonomy. Subject governs over music through the rational system and at the same time he undergoes to the same system, which is the new marxist paradigma of reversed progress. Adorno's previously proclaimed historical inevitability, the empire of freedom (Reich der Freiheit) became a straitjacket, a lost of the freedom. Music as a technical work, subjugated to the technique and constructivism, inevitably failed.

Schönberg sharply disagreed with Adorno's interpretation of his twelve-tone system. Later Adorno himself recognized his interpretation to be a distortion, and "redirected" his criticism the serialism. But a kind of ambivalence,inconsistence in relation to Schönberg music persisted.

The more moderate criticism of dodecaphony, but similar to the later marxist discours in Philosophie der neuen Music was formulated in Adorno's set of possible, quasi encyclopedic entries, or short articles, Neunzehn Beiträge über neue Musik (1942), ${ }^{25}$ in the article Konstruktion in der neuen Musik. A prominent status was attributed to the constructivism in the 20th century music.According to article, the constructivism is a focus where various lines in the development of new music converge (Fluchtpunkt der Entwicklungslinien der neuen Musik). ${ }^{26}$ Adorno's concepts Konstruktion, integrales Kunstwerk, durchorganisierte Einheit, refer to the principle of strict economy (austerity), where nothing redundant is left. The principle of total determinancy governs every element which is subdued to a predetermined wholeness. Implications of such a constructivism are statism, the elimination of tensions and expresivity, and of blind, irrational elements of dynamism. Alle blinden treibenden, irrationalen Momente werden liquidiert: daher die virtuelle Statik, daher auch die kritische, obgleich nicht blank eindeutige

23 WEBER, Max. Die protestantische Ethik und der Geist des Kapitalismus. WEBER, Max. Gesammelte Aufsätze zur Religionssoziologie. 1. Tübingen: J. C. B. Mohr, 1920, S. 203-204.

24 Igor Stravinsky in the second part Stravinsky und Restauration of book Philosophie der neuen Musik is an epitome of a decline of the $20^{\text {th }}$ century music as an example of commertionalisation and marketisation of the musical culture.

25 ADORNO, Theodor Wiesengrund. Gesammelte Schriften in 20 Bänden, op. cit., Band 18, p. 81-82.

26 Ibidem, p. 82. 
Stellung zum Moment der Expression ${ }^{27}$ Such a music is heading to a technical self in itself Das Kunstwerk nähert sich dem Bilde absoluter technischer Zweckmässigkeit in sich selber an. The dodecaphony is in a danger to be not means to an artistic end but a technical end itself. A large part of dodecaphony heading to this concept of composition was a subject of Adorno's fierce criticism.

In Adorno's essay On current relationsship of philosophy and music (Über das gegenwärtige Verhältniss von Philosophie und Musik, 1953), rationality and constructivism imply a receding, dying of language dimension in modern music, Absterben des musikalischen Sprachelements, thus a crisis of modern music. The principle of total construction, integral composition which Schönberg school was striving for, was colliding with a language character of music, striving elimination of speech character. "Das Prinzip der Durchkonstruktion des Materials bei Schönberg, des integralen Komponierens das seine Schule anstrebt, stösst mit der Sprachlichkeit der Musik zusammen." ${ }^{28}$

Antagonism, contradiction, or tension between construction and speech - language character of music is an issue of central importance in Adorno's interpretation of Schönberg and serialism. It is the topic of Sprachlichkeit der Musik, a specific concept of language of music, or similarity, kinship and difference between them: when Adorno was speaking of music as interpretation, mimicking (mimesis), not decoding (Deschifrierung) of meaning, it was an appeal to a hermeneutic epistemological tradition of language, epitomised for him in language concept of W. Benjamin, or similar to L. Wittgenstein, not an appeal to tradition of lingustic structuralism (semiotic) of F. Sausurre, ${ }^{29}$ or to ortodox structuralism of the linguist L. Bloomfield. Manifestation of this linguistic tradition as a an ultra, ultra-structuralistic musical metalaguage, metasyntax, was an ideal of P. Boulez, who in lecture in Colledge de France 1978 declared: "la musique ne signifie rien, elle n'est pas une sorte d'alphabet superieure” („music signifies nothing, it is not a kind of higher alphabet"). However, it was not an ideal of Adorno. Adorno's hermeneutical concept of language epitomized irrational polarity, or an irrational counterpart to rational construction. In this meaning polarity of construction and language was a basis of Adorno's posthumous work Aesthetic Theory (Ästhetische Theorie, 1970), which is also about Schönberg's music.

In Schönberg's dodecaphonic compositions, as Valse from Five Pieces for Piano, op. 23, in Suite for piano, op. 25, Windquintet, op. 26, String Quartett, No. 3, op. 30, Variations for Orchestra, op. 31 there are tendencies of constructivism and determinism, Durchkonstruktion and Intergrales Komponieren, by Adorno mentioned tendencies of eliminating expressionism and subjectivity. There is a contradiction, collision between construction and language. According to Schönberg's declaration, once music conquered new (constructive) dimension, other dimensions are receding. But these tendencies of constructivism never fully subjugated his music. Auf jeder Stufe sind Schönberg Kräfte polaren Wesens am

27 Ibidem, p. 82.

28 ADORNO, Theodor W. Über das gegenwärtige Verhältnis von Philosophie und Musik. In ADORNO, Theodor Wiesengrund. Gesammelte Schriften in 20 Bänden, op. cit., Band 18, p. 173.

29 ADORNO, Theodor W. Fragment über Musik und Sprache. In ADORNO, Theodor Wiesengrund. Gesammelte Schriften in 20 Bänden, op. cit., Band 16, p. 253. 
Werk:die des fessellosen, befreiten, authentischen Ausdrucks und die einer Durchkonstruktion, die noch das letzte Detail, die flüchtige Regung in sich hineinzieht. ${ }^{30}$

\section{Bibliography}

ADORNO, Theodor Wiesengrund. Dialektik der Aufklärung. Philosophische Fragmente. In ADORNO, Theodor Wiesengrund. Gesammelte Schriften in 20 Bänden. Band 3. Frankfurt am Main: Suhrkamp, 1981.

ADORNO, Theodor Wiesengrund. Philosophie der neuen Musik. In ADORNO Theodor Wiesengrund. Gesammelte Schriften in 20 Bänden. Band 12. Frankfurt am Main: Suhrkamp, 1990.

ADORNO, Theodor Wiesengrund. Zur Zwölftontechnik. In ADORNO, Theodor Wiesengrund. Gesammelte Schriften in 20 Bänden. Musikalische Schriften V, Band 18. Frankfurt am Main: Suhrkamp, 1984, S. 361-369.

ADORNO,Theodor Wiesengrund. Über das gegenwärtige Verhältnis von Philosophie und Musik. In ADORNO, Theodor Wiesengrund. Gesammelte Schriften in 20 Bänden. Musikalische Schriften V, Band 18. Frankfurt am Main: Suhrkamp, 1984, S. 361-369.

BOULEZ, Pierre. Boulez on Music Today. Cambridge-Massachusetts: Harvard University Press, 1971.

GOLDMAN, Jonathan. The Musical Language of Pierre Boulez. Writings and Compositions. Cambridge: Cambridge University Press, 2011.

KLEIN, Richard, KREUTZER, Johann, MÜLLER-DOOHM, Stephan (Hrsg.). Adorno Handbuch / Leben-Werk-Wirkung. Stuttgart-Weimar: Verlag J. B. Metzler, 2011.

LEIBOWITZ, René. Schönberg et son école. L'etat contemporaine du langage musicale. Paris 1947.

SCHÖNBERG, Arnold. Style und Idea. New York: Philosophical Library, 1950.

30 ADORNO, Theodor Wiesengrund. Zum Verständniss Schönbergs. In ADORNO Theodor Wiesengrund. Gesammelte Schriften in 20 Bänden, Band 18, S. 442. 